Haya: The Saudi Journal of Life Sciences

Abbreviated Key Title: Haya Saudi J Life Sci

ISSN 2415-623X (Print) |ISSN 2415-6221 (Online)

Scholars Middle East Publishers, Dubai, United Arab Emirates

Journal homepage: https://saudijournals.com

Review Article

\title{
Clinical Interpretation of Hypothyroidism in Unani Medicine
}

\author{
Shiekh Zahoor Ahmad ${ }^{1 *}$, Arsheed Iqbal ${ }^{1}$, Haider Ali Quraishi ${ }^{1}$, Asma Afzal ${ }^{1}$, Afrooza Jan ${ }^{2}$, Naquibul Islam ${ }^{3}$, Shameem \\ Ahmad Rather ${ }^{4}$ \\ ${ }^{1}$ PG Scholars, Department of Moa'lajat, Regional Research Institute of Unani Medicine, University of Kashmir, Jammu \& Kashmir, India \\ ${ }^{2}$ Assistant Professor, Dept. of Physiology, Government Unani Medical College, Ganderbal, Srinagar, Kashmir, India \\ ${ }^{3}$ Professor, Department of Moa'lajat, Regional Research Institute of Unani Medicine, University of Kashmir, Jammu \& Kashmir, India \\ ${ }^{4}$ Reader, Department of Moa'lajat, Regional Research Institute of Unani Medicine, University of Kashmir, Jammu \& Kashmir, India
}

DOI: $10.36348 /$ sjls.2021.v06i01.002

| Received: 22.12.2020 | Accepted: 04.01.2021 | Published: 08.01.2021

*Corresponding author: Dr. Shiekh Zahoor Ahmad

Abstract

Background: Hypothyroidism in the simplest terms can be defined as deficient production of thyroid hormone. Primary hypothyroidism indicates decreased secretion of thyroid hormone by factors affecting the thyroid gland itself. A decrease in serum concentrations of thyroid hormone causes an increased secretion of Thyroid Stimulating Hormone (TSH), thus resulting in elevated serum TSH concentration [1-4]. Even though, classical texts of Unani Medicine does not have mention of Hypothyroidism, but the clinical features of Hypothyroidism resemble with the Alamat-wa-awarizat (clinical features) of su'- mizaj barid /su'- mizaj balghami (impaired cold temperament/impaired phelgematic temperament) . In this context, a hypothesis was drawn that $s u^{\prime}$ - mizaj barid $/ s u^{\prime}$ - mizaj balghami (impaired cold temperament/impaired phelgematic temperament) may be interpreted with the clinical features of hypothyroidism using modern scientific parameters.

Keywords: Hypothyroidism, Thyroid stimulating hormone, sue-mizaj barid, sue-mizaj balghemi.

Copyright () 2021 The Author(s): This is an open-access article distributed under the terms of the Creative Commons Attribution 4.0 International License (CC BY-NC 4.0) which permits unrestricted use, distribution, and reproduction in any medium for non-commercial use provided the original author and source are credited.

\section{INTRODUCTION}

Hypothyroidism in the simplest terms can be defined as deficient production of thyroid hormone. Primary hypothyroidism indicates decreased secretion of thyroid hormone by factors affecting the thyroid gland itself. A decrease in serum concentrations of thyroid hormone causes an increased secretion of Thyroid Stimulating Hormone (TSH), thus resulting in elevated serum TSH concentration [1-4]. Estimates of incidence of hypothyroidism vary depending on the population studied. In the United states, $0.3 \%$ population have overt hypothyroidism and $4.3 \%$ have subclinical or mild hypothyroidism [5]. The incidence of hypothyroidism is higher among women, in the elderly, and in some ethnic and racial groups $[8,9]$. The incidence of Hypothyroidism in India have a female to male ratio of $6: 1$. The prevalence of hypothyroidism in India is $11 \%$, compared with only $2 \%$ in the UK and $4.6 \%$ in the USA. The prevalence of hypothyroidism in India varies depending upon the location. The cities like Kolkata, Delhi, Ahmedabad, Bangalore, and Hyderabad located inland have a higher prevalence of $11.7 \%$ compared with coastal cities like Mumbai, Goa, and Chennai having 9.5\%. According to Ambrish Mithal, the reason behind the higher mean thyroid -stimulating hormone concentration and range in India compared with western countries is possibly linked to longstanding iodine deficiency in the country, which has only been partly corrected over the past 20 years. The highest prevalence of hypothyroidism upto $13.1 \%$ is noted in people aged 46-54 years, with people aged 18 35 years being less affected upto $7 \cdot 5 \%$ [6-8].

\section{Historical Background}

Endocrinology is a Scientific and Medical Discipline with a unique focus on hormones and features a multidisciplinary approach to understanding hormones and their diseases. About a hundred years ago, Starling coined the term hormone to describe secretin, a substance secreted by the small intestines into the blood stream to stimulate pancreatic secretion. In his croonian lectures, Starling considered the endocrine and nervous systems as two distinct mechanisms for coordination \& control of organ function. Thus, endocrinology found its first home in the discipline of mammalian physiology [9-11].

Work over the next several decades by Biochemists, Physiologists and Clinical investigators led to the characterization of many hormones secreted into the blood stream from discrete glands or other 
organs. These investigations showed that diseases such as hypothyroidism and diabetes could be treated successfully for the first time by replacing specific hormones. These initial triumphs formed the foundation of the clinical specialty of endocrinology. Endocrine diseases fall into broad categories of hormones, over or under production, altered tissue response to hormones, or tumors arising from endocrine tissue. Hormones can be defined as chemical signals secreted into the blood stream that act on distant tissues, usually in a regulatory fashion [12].

The history of thyroid gland and its swellings are deeply intertwined and go back several centuries. Some of the earliest recorded descriptions of the thyroid gland originated from China, but most of the information was confined to Chinese sub- continent. The first description of goiter dates back to 2700 B.C., when people living in the mountainous region of China were described to have both goiter and baldness, and were treated with a combination of burnt sponge, algae and seaweed. The Chinese had developed the practice of treating children with cretinism with sheep and deer thyroid. They also recognized various forms of benign and malignant goiters [13, 14].

Ayurveda, the ancient medical science of India, used the term 'galaganda' to goiter as early as 1400 B.C. The word 'galanganda', when translated, means the gland in the neck. Ancient Ayurvedic texts have described remedies for the treatment of goiter ${ }^{5}$.Many centuries later, Buqrat (Hippocrates 460377 B.C.) named the goiter as 'struma'. Around that period, goiter was also referred to as 'chorion' and 'gongroma'. Aurellius Celsus and Gaius Plinius were the main contributors to the understanding of thyroid disease in the Greeco-Roman period which extended till around 500 A.D [10-13].

Great Greeko -Roman physician Jalinus (Galen 130-200 A.D.), postulated that the secretions from thyroid gland were important for the lubrication of larynx. He also documented that surgery in the area of thyroid gland made many patients mute by damaging the laryngeal nerves [14-16].

'Ali ibn 'Abbas Majusi (930-994 A.D.) described surgery of goiter as early as in 990 in his book Kamil al-Sana't [16, 17].

Great surgeon of his times Abul Qasim Zuhrawi (936-1036 A.D.) who is considerd the father of surgery has successfully operated a swelling of throat which was in fact a goiter $[16,18]$.

Ibn-Hubul Baghdadi (1122-1213 A.D.) has mentioned Hujuzul ain (exopthalmic goiter) in his book 'Kitabul Mukhtarat fil Tib' [16, 19] (a clssical unani medical text).
Ismail Jurjani (12th century) first described protrusion of eyes (exopthalmos) which is considered an important sign of Grave's disease [16, 20].

Andreas Vaelius who first published a description of the thyroid gland as an anatomical rather than pathological organ in his classic paper in 1543, titled 'De Humani Corporis Fabrica'. He also noted that secretions of the gland were sticky and fat filled, and he speculated that this was important for voice modulation [21].

Ultimately it was Thomas Warton (1614-1673) who gave name to the gland from the greek word 'shield shaped' because of the shape of nearby thyroid cartilage [22].

The possibility that thyroid secreted some fluid into the veins was first proposed by Frederik Ruysch in 1690. This was confirmed many years later in 1836 by Thomas Wilkinson king of Guys Hospital, London who is known as Father of Endocrinology [14]. Sir William Withey Gull first gave a detailed description of classic clinical signs of hypothyroidism in an adult woman including macroglossia and hoarse voice and were published in 1873. In 1878, William Ord of St. Thomas Hospital proposed the term myxedema for the condition caused by destruction of thyroid [23-25].

\section{INTERPRETATION OF HYPOTHYROIDISM IN UNANI MEDICINE}

Even though Classical Unani texts does not have a direct encompass on Qillat-i- Ifraze Darqia (Hypothyroidism), but Unani Physicians were well aware of various endocrine glands and their disease conditions and treatments like organo therapy were well known treatment for various such disorders [9, 10]. Buqrat (Hippocrates 460-377B.C.) the father of medicine has named the goiter as 'struma'. Jalinus (Galen 130-200A.D.) the great Greeko-Roman physician(who did pioneering work in the understanding of many diseases) postulated that secretions from thyroid gland were important for lubrication of the larynx.He also documented that surgery in the area of thyroid gland made many patients mute by damaging the laryngeal nerves. 'Ali ibn 'Abbas Majusi (930-994 A.D.) in his famous book 'kamil alsana't (a classical unani medical text) narrated that the waram (swelling) which occurs due to accumulation of Balgham al- Ghaleez (abnormal phelgem) results in 'Ghainga' which are similar to glands The great Unani surgeon of time Abul Qasim Zahrawi (936-1036 A.D.) who is known as father of surgery has mentioned an operation on thyroid in his book 'Kitab al- Tayasar Fi'l Madaw'at al-Tadbeer'(a classical unani medical text).Ibn Hubul Baghdadi (1122-1213 A.D.) narrated in his book 'kitab al-Mukhtarat Fi'l Tibb' (a classical unani medical text) Hujuzul ain which means exopthalmic goiter.Another Unani Physician Ismail Jurjani ( 12th century) described protrusion of eyes in 
his book 'Dhakhira Khawarizm Shahi'(a versatile classical medical text) which is now an important sign of Grave's disease [15-20].

But no classical Unani text has a direct mention of Qillat-i- Ifraze Darqia as such. In Unanidoctrine, the basic causes of disease are grouped under three headings:-

Su'- Mizaj [26] (impaired temperament)

Su'- Tarkib [26] (abnormal structure/composition)

Tafarruq-i-Itisaal [26] (discontinuity)

Su'- Mizaj (impaired temperament) is defined as an alteration, deviation, or imbalance in the normal temperament of a person or organ which causes disturbance or derangement of bodily functions or organ.

Su'- Mizaj (impaired temperament) is divided into 2 main types:-

1. Su'- MizajSada ( simple impaired temperament)

2. Su'- MizajMaddi (impaired substantial temperament)

Su'- Mizaj is divided into four types:-

1. Su'- Mizaj Harr (impaired hot temperament)

2. Su'- Mizaj Barid (impaired cold temperament)

3. Su'-Mizaj Ratb (impaired moist temperament)

4. Su'- Mizaj Yabis. (impaired dry temperament)

Su'-Mizaj of any type produces particular clinical features which are determintal to it, and help the Physician in Diagnosis and management of the particular disease. The symptoms and signs of $\mathrm{Su}^{\prime}-$ Mizaj Barid Maddi/Su'-Mizaj Balghami (impaired substantial cold temperament/(impaired phelgematic temperament)are:- kusul wa mandgi ( somnolence), Thakan (fatigue),Tahabbuj (Puffiness), Kathrat alBuzaq (excessive salivation), du'f al-Ishtiha (loss of appetite),kathrat al-nawm (excessive sleep),du'f al-bah (loss of libido),kund zehi (decreased intellectual functions),Burd-atraaf (cold extremities), Qabd (constipation),Nabd Bati wa Mutafawit (pulsus tardus and pulsus rarus ) etc [16, 17, 26-34].

As far as the clinical features of Hypothyroidism (Qillat-i-Ifraze Darqia ) are concerned, these somehow resemble with the symptoms and signs of su'-mizaj barid maddi/Su'-Mizaj Balghami) (impaired substantial cold temperament/(impaired phelgematic temperament) which almost all great Unani Physicians like Ibn Sina (980-1037 A.D.),IbnRushud(1126-1198 A.D.), Ibn -Hubul Baghdadi (11221213 A.D.),Zakaria Razi (860-925 A.D.)in their respective treatises like Al-Qanun Fi'l-Tibb (The Canon of Medicine),Kitab al-Kulliyyat (Basics of Unani Medicine), Kitab al-Mukhtarat fi'l Tibb(A classical unani medical text),Kitab al-Mansuri (A classical unani medical text),respectivelyhave described in detail.

In context of the above descriptions,primary hypothyroidism may be categorized as a su'-mizaj barid maddi/su'-mizaj balghami (impaired substantial cold temperament/(impaired phelgematic temperament) mar'd(disease)of Unani system of medicine.

Table-1

\begin{tabular}{|l|l|}
\hline Symptoms and signs of Su' Mizaj Barid Maddi(Balghami) [27-34] & Symptoms and Signs of Hypothyroidism [1-9] \\
\hline Kusul wa mandgi & Somnolence \\
\hline Thakan & Fatigue \\
\hline Buhha al-sawt & Hoarseness of voice \\
\hline Tahabuj & Puffiness of face \\
\hline Du'f' al-bah & Loss of libido \\
\hline Du'f al-Ishtiha & loss of appetite \\
\hline Barudati badan & Hypothermia \\
\hline Qabd & Constipation \\
\hline Nisyan & Dementia \\
\hline Kathrat al-nawm & Excessive sleep \\
\hline Nabd bati w Mutafawit & slow and delayed pulse \\
\hline
\end{tabular}

\section{CONCLUSION}

Hence, from all the above discussions, it may be concluded that Hypothyroidism is a su'-mizaj barid maddi/su'-mizaj balghami (impaired substantial cold temperament/(impaired phlegmatic temperament) disease of Unani Medicine.

\section{REFRENCES}

1. Vaidya, B., \& Pearce, S. H. (2008). Management of hypothyroidism in adults. BMJ. 337:a801.
2. Almandoz, J. P., \& Gharib, H. (2012). Hypothyroidism: etiology, diagnosis and management. Med Clin North Am. 96:203-2221.

3. Jabbar, P. K., \& Danish, E. (2012). Hypothyroidism: Introduction, etiology and clinical features. ITS Clinical Manual of Thyroid Disorders, RV Jayakumar, First ed. Elsevier Limited. 129-30.

4. Gull, W. W. (1874). On a cretinoid state supervening in adult life in women. Trans Clin Soc London. 7:180. 
5. Cooper, D. S., \& Biondi, B. (2012). Subclinical thyroid disease. Lancet. 379:1142-1154.

6. Persani, L. (2012). Clinical review: central hypothyroidism: pathogenic, diagnostic and therapeutic challenges. J Clin Endocrinol Metab. 97:3068-3078.

7. Jabbar, P. K., \& Danish, E. (2012). Hypothyroidism: Introduction, etiology and clinical features. ITS Clinical Manual of Thyroid Disorders, RV Jayakumar, First ed. Elsevier Limited. 129-30.

8. Gull, W. W. (1874). On a cretinoid state supervening in adult life in women. Trans Clin Soc London. 7:180.

9. Melmed, P., \& Larsen, K. (2016). Williams Text Book of Endocrinology. 13th ed. RELX India. Pvt. Ltd; 2-4.

10. Harish, K., \& Nisha, B. (2012). History of Thyroid disease, ITS Clinical Manual of Thyroid Disorders, RV Jayakumar, First ed. Elsevier Limited. 1-4.

11. Needham, J. (1970). Proto-endocrinology: thyroid function. In: Clerks and craftsmen in China and the West: Lectures and addresses on the History of sciences and technology Cambridge, UK: Cambridge University press. 298-302.

12. Temple, R. (2007). The Genius of China: 3000 years of science, Discovery and invention $3^{\text {rd }}$ ed. London, UK: Deutsch. 147-8.

13. Hume, E. H. (1924). The contributions of China to the science and art of medicine. Science. 59:34550.

14. http/www.ehow.com/about-history-thyroiddisease.html(cited on 2010 oct10)

15. Gallen, C. (1929). Introduction to History of Medicine $4^{\text {th }}$ ed. Saunders.

16. Hannan. (2001). Laqanati rasilat aur attibae qadeem. Jahane Tib. 7(2):56-60.

17. Majoosi, A. (1889). Kamil al- Sana't (Urdu Translation by Kantoori GH) Vol.I. Lucknow: Munshi Nawal Kishore. 25,28,426.

18. Ibn Zuhar. (1986). Kitab al-Tayser (Urdu Translation). New Delhi: CCRUM. 234-235.106.

19. Baghdadi, A. A. B. H. (2004). Kitab al-Mukhtarat Fi'l Tibb (Urdu Translation) Vol. III. New Delhi: CCRUM. 105.
20. Jurjani, I. (1996). Dakhira Khawarzim Shahi (Urdu Translation by Khan HH) Vol. VII. Lucknow: Munshi Nawalk Kishore. 35,36.

21. Rolleston, H. D. (1936). The Endocrine Organs in Health and Disease with a Historical Review Oxford, UK: Oxford University press. 18,268,174-7,193,203.

22. Wharton, T. (1996). Adenographia Freer S, trans. Oxford, UK: Clarendon Press, (Is ted, 1656):700.

23. Coindet, J. F. (1820). De couverte d' un nouveau remede contre le goiter. Ann Chim Phys. 15:49. Originally published in the Swiss Bibilioteque Universelle 1820 , and reprinted in its entirely in $\mathbf{J}$ Pharmacie. 6; 485.

24. Marine, D., \& Kimball, O. P. (1920). The prevention of simple goiter in man: fourth paper. Arch Intern Med: 25:661-72.

25. King, T. W. (1836). Observations on the thyroid gland. Guy's Hosp. Rep; 1:429-46.

26. Ibn Sina. (2007). Al- Qanun Fi'l Tibb. (Urdu Translation by Kantoori GH) Vol.i. New Delhi: Idara Kitabul Shifa: 855.

27. Kabeer, U. M. (2007). Kulliyat -i- Qanun (Urdu Translation) Vol.1.New Delhi: Aijaz Publishing House: 240,356.

28. Ahmad, S. I. (1983). Kulliyat-i-'Asri'. New Delhi: Public Press: 66-69.

29. Azmi, A. A. (1995). Basic Concepts of Unani Medicine. Ist ed. New Delhi: Jamia Hamdard, Hamdard Nagar: 60-66.

30. Ahmad, S. I. (1980). Introduction to Al- Umur alTabbi'ya. Ist ed. New Delhi: Saini Printers: 50$54,58,59$.

31. Tabri, A. A. M. (1997). Moalijat al-Buqratiya. (Urdu Translation) CCRUM. Vol.III. New Delhi: Ministry of H \& FW; 21,28,202,203,338.

32. Khan, M. A. (2003). Al-Akseer (Urdu Translation by Kabirudin) Vol.I. \& Vol. II. New Delhi: Aijaz Publishing House: 27,29,631,632,573,810.

33. Zaidi, I. H., Zulkifle, M., \& Ahmad, S. N. (1999). Temperamentology-A scientific appraisal of Human Temperament. Ist ed. Aligarh: AMU: 18(19):68-98.

34. Ibn Rushud, A. W. M. (1987). Kitab al- Kulliyat (Urdu Translation) $2^{\text {nd }}$ ed. New Delhi: CCRUM: 360-363. 